\title{
An Unusual Case of Signet Ring Cell Cholangiocarcinoma- Case Report and a Review of Literature
} \author{
Dankour Alian ${ }^{5}$, Paz Kalman ${ }^{5}$ and Lurie Yoav ${ }^{6}$ \\ ${ }^{1}$ Faculty of Medicine, Hebrew university of Jerusalem, Israel \\ ${ }^{2}$ Department of Surgery, Sha'are Zedek Medical center, Israel \\ ${ }^{3}$ Department of Radiology, Sha'are Zedek Medical center, Israel \\ ${ }^{4}$ Department of pathology, Sha'are Zedek Medical center, Israel \\ ${ }^{5}$ Department of gastroenterology, Sha'are Zedek Medical center, Israel \\ ${ }^{6}$ Liver unit, Sha'are Zedek Medical center, Israel
}

Shechter Yonat ${ }^{1 *}$, Dagan Amir ${ }^{2}$, BenHaim Menahem², Bar-Ziv Yaakov ${ }^{3}$, Brazowski Eli , Shteingart Shimon ${ }^{4}$,

Submission: January 10, 2017; Published: June 16, 2017

"Corresponding author: Yoav Lurie, Liver Unit, digestive disease institute, Sha'are Zedek medical center, Jerusalem, Israel, Fax: +972-2-6555359; Tel: +972-2-6555035; Email: Yoavtalitami@gmail.com

\begin{abstract}
Cholangiocarcinoma is an uncommon adenocarcinoma with poor prognosis. Signet ring cell cholangiocarcinoma is an extremely rare disease, with only 11 cases reported to date. However, its incidence is increasing. Interestingly, there is increased incidence of other SRC tumors (colon, gastric, etc.) as well. Most cases have described a localized mass of signet ring cells, most commonly in the common bile duct. In our report, a 69-year-old Caucasian man presented with jaundice and abdominal pain of three days. The patient underwent a CT scan, ERCP, and EUS as part of his initial workup. Biopsies were obtained during EUS from the CBD disclosing signet ring cholangiocarcinoma. ERCP showed a diffusely infiltrative tumor of both left and right hepatic ducts. This appears to be the first description of diffuse type signet ring cell cholangiocarcinoma. Unfortunately, the patient experienced rapid clinical deterioration which precluded treatment. Survival was extremely short-the patient passed away three weeks after initial appearance of symptoms. As the incidence of SRC's in general, as well as the incidence of SRC cholangiocarcinoma appear to be on the rise, more cases are likely to be encountered. If our observation of the extremely virulent presentation of diffuse-type SRC cholangiocarcinoma is confirmed, perhaps palliative care only should be considered in these patients at the onset.
\end{abstract}

Keywords: Cholangiocarcinoma; Signet ring cell; ERCP; EUS

Abbreviations: CC: Cholangiocarcinoma; SRC: SignetRingCell;CBD: Common Bile Duct,ERCP: Endoscopic RetrogradeCholangiopancreatography, EUS: Endoscopic Ultrasound, CT: Computed Tomography

\section{Introduction}

Cholangiocarcinoma (CC) is a mucin producing adenocarcinoma that arises from bile duct epithelium [1]. It is an uncommon adenocarcinoma with poor prognosis (5-year survival is less than $5 \%$ ) and most patients initially present with advanced disease [2]. Cholangiocarcinomas are grouped by their anatomic site of origin in descending order: Hilar (65\%), Distal (30\%) and Intrahepatic. Diagnosis is made by biopsy, usually obtained via endoscopic retrograde cholangiopancreatography (ERCP) [1].
Signet-ring-cell (SRC) Cholangiocarcinoma is an extremely rare variant, with only 11 cases reported to date [3-13]. All cases describe a localized mass, usually in the extrahepatic biliary tract. To the best of our knowledge, this is the first reported case of diffuse SRC cholangiocarcinoma, with no distinct mass on imaging studies. Furthermore, the patient we describe had a fulminant course of disease, with only 3 weeks separating initial presentation to patient death. 


\section{Case Report}

The patient is a 69-year-old male with no significant past medical history of Ashkenazi Jewish descent. The patient presented with new onset Jaundice and a three-day history of abdominal pain. He further denied any previous gastrointestinal illness. Blood chemistry showed: total Bilirubin $4.8 \mathrm{mg} / \mathrm{dl}$, AST 305IU/L $(\mathrm{N}<40)$, ALT 374IU/L $(\mathrm{N}<70)$, ALP 571IU/L $(\mathrm{N}<150)$, GGT $1925 \mathrm{IU} / \mathrm{L}(\mathrm{N}<73)$ and CA 125 was $45.9 \mathrm{U} / \mathrm{ml}(\mathrm{N}<35)$. serum electrolytes, CA 19-9, creatinine and amylase were found to be within normal limits. Abdominal Computed Tomography (CT) showed mild dilatation of intrahepatic bile ducts, predominantly in the rightlobe, and a dilated gallbladder containinggallstones. No other abnormality was found (Figure 1). Endoscopic ultrasound
(EUS) showed strictures of the left hepatic duct, proximal bifurcation of common hepatic duct, and common bile duct (the right hepatic duct could not be visualized). Needle biopsies were taken from the proximal common bile duct (CBD) and from an enlarged lymph node in the porta hepatis. The biopsies showed poorly differentiated signet ring adenocarcinoma. The tumor was at least stage IIIB (T1-3, N=1, M=0) [14]. An ERCP was also performed, showing multiple PSC-like strictures and beadings in the intrahepatic bile ducts. Attempted plastic stent insertion to the left system failed twice, and a metallic uncovered stent was inserted into distal right system. Colonoscopy was normal and didn't show any other site of primary malignancy explaining the signet ring cell carcinoma.

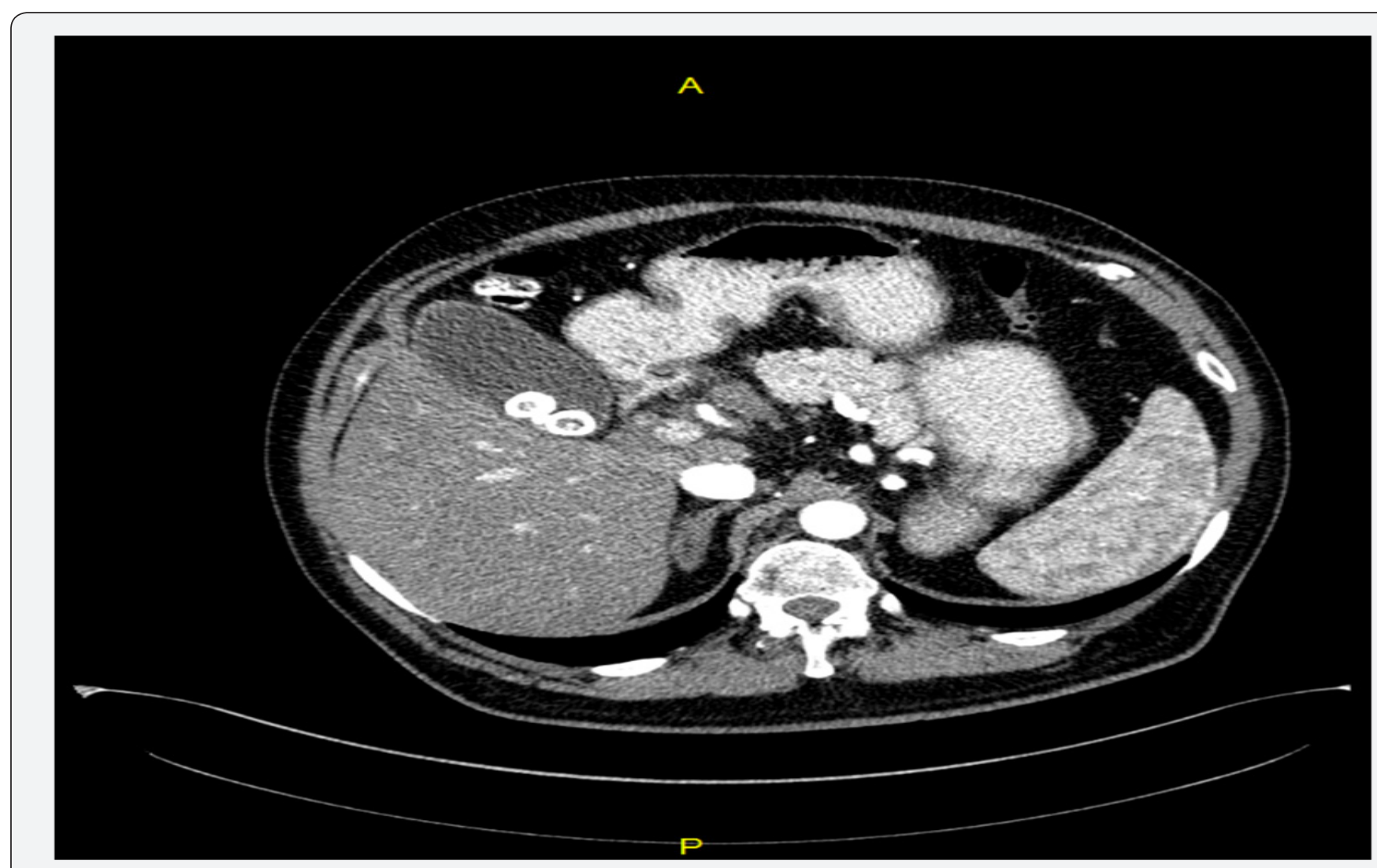

Figure 1: Computed tomography (CT), shows no evidence of tumor in the stomach. A- Body of stomach B- Pylorus of stomach. CGallstones.

Unfortunately, once the diagnosis was made the patient experienced rapid clinical deterioration-bilirubin levels increased to $21.3 \mathrm{mg} / \mathrm{dl}$ and ALP levels rose to 1579 , despite partial drainage. Several days after clinical deterioration, and only three weeks after initial presentation, the patient expired.

\section{Discussion}

Signet Ring Cells (SRCs) are characterized by a thin intracellular circle with a thicker nuclear projection to one side, thereby imitating a signet ring. Their shape is created by loss of function of the tumor suppressor gene CHD1, leading to the loss of the cell adhesion protein E-cadherin. Thus, these cells cannot form normal glands, mucin cannot be secreted and accumulates in large vacuoles that expand the cytoplasm and push the nucleus to the periphery, creating a signet-ring cell morphology [15]. SRC tend to infiltrate the mucosal wall diffusely, thickening it [15]. It presents mainly in the stomach but may also present in other organs - colon, prostate, bladder, and others [16]. Regardless of its location, SRC carcinoma carries a poorer prognosis when compared to non-SRC carcinomas because of a higher prevalence of peritoneal carcinomatosis and lymph node invasion at initial diagnosis and lower $\mathrm{R} 0$ resection rate due to its infiltrative nature [17]. This rule also applies to SRC biliary carcinoma (Table 1). 
Despite the overall decrease in the incidence of gastric cancer, the incidence of SRC gastric carcinoma is increasing, especially in western countries [16]. The incidence of signet ring cell colorectal carcinoma is increasing as well [18]. SRC carcinoma of the biliary tract, first described in 1999, is extremely rare with only eleven cases described so far. Nevertheless, a clear trend of

Table 1: Review of the reported cases of signet ring cell Cholangiocarinoma.

\begin{tabular}{|c|c|c|c|c|c|c|c|c|c|}
\hline No. & Author & Gender & Age & Ethnicity & Diffuse/ localized & $\begin{array}{l}\text { Diagnostic } \\
\text { method }\end{array}$ & $\begin{array}{l}\text { Survival } \\
\text { time }\end{array}$ & Treatment & Symptoms \\
\hline 1 & $\begin{array}{c}\text { Mizukami et al. } \\
{[10]}\end{array}$ & M & 74 & Asian & Localized perihilar & Autopsy & 4 weeks & None & Jaundice \\
\hline 2 & Hiraki et al. [4] & $\mathrm{F}$ & 78 & Asian & $\begin{array}{l}\text { Localized } \\
\text { distal CBD }\end{array}$ & $\mathrm{N} / \mathrm{A}$ & 3 months & $\mathrm{N} / \mathrm{A}$ & $\mathrm{N} / \mathrm{A}$ \\
\hline 3 & Lee et al. [8] & M & 55 & Asian & $\begin{array}{c}\text { Localized } \\
\text { Distal CBD + Ampulla } \\
\text { of Vater }\end{array}$ & ERCP & 1 year $\mathrm{F} / \mathrm{U}$ & $\begin{array}{l}\text { PPPD+ } \\
\text { Chemorad- } \\
\text { iotherapy }\end{array}$ & $\begin{array}{l}\text { Jaundice, } \\
\text { pruritus }\end{array}$ \\
\hline 4 & $\begin{array}{c}\text { Ogata et al. } \\
\text { [11] }\end{array}$ & $\mathrm{F}$ & 42 & Asian & $\begin{array}{l}\text { Localized } \\
\text { CBD }\end{array}$ & $\begin{array}{c}\text { surgical } \\
\text { specimen }\end{array}$ & $\begin{array}{c}6 \text { months } \\
\mathrm{F} / \mathrm{U}\end{array}$ & $\mathrm{PD}+$ & Jaundice \\
\hline 5 & $\begin{array}{l}\text { Matsumoto et } \\
\text { al. [9] }\end{array}$ & M & 72 & Asian & $\begin{array}{l}\text { Localized } \\
\text { CBD }\end{array}$ & $\mathrm{N} / \mathrm{A}$ & 3 months & $\begin{array}{c}\text { Subtotal } \\
\text { Gastrectomy }\end{array}$ & Jaundice \\
\hline 6 & $\begin{array}{l}\text { Sommer et al. } \\
{[12]}\end{array}$ & $\mathrm{F}$ & 66 & $\mathrm{~N} / \mathrm{A}$ & $\begin{array}{c}\text { Localized } \\
\text { hepatic bifurcation }\end{array}$ & $\begin{array}{l}\text { Surgical } \\
\text { specimen }\end{array}$ & $\mathrm{N} / \mathrm{A}$ & Chemotherapy & $\begin{array}{c}\text { Abdominal } \\
\text { pain, jaundice }\end{array}$ \\
\hline 7 & Kita et al. [6] & $\mathrm{F}$ & 73 & Asian & $\begin{array}{l}\text { Localized } \\
\quad \text { CBD }\end{array}$ & ERCP & 1 year $\mathrm{F} / \mathrm{W}$ & $\begin{array}{l}\text { Resection of } \\
\text { extrahepatic } \\
\text { biliary tree }\end{array}$ & Jaundice \\
\hline 8 & Kwon et al. [7] & M & 63 & Asian & $\begin{array}{l}\text { Localized } \\
\text { CBD }\end{array}$ & $\begin{array}{c}\text { Surgical } \\
\text { specimen }\end{array}$ & 15 months & PPPD & $\begin{array}{c}\text { Epigastric } \\
\text { pain, jaundice }\end{array}$ \\
\hline 9 & $\begin{array}{l}\text { Chedid et al. } \\
\text { [3] }\end{array}$ & $\mathrm{F}$ & 66 & Caucasian & $\begin{array}{c}\text { Localized } \\
\text { Right }+ \text { left hepatic duct } \\
\text { bifurcation }\end{array}$ & $\begin{array}{l}\text { Surgical } \\
\text { specimen }\end{array}$ & 15 months & PPPD & $\begin{array}{c}\text { Fatigue, } \\
\text { Anorexia, } \\
\text { Jaundice, Pale } \\
\text { stools. }\end{array}$ \\
\hline 10 & Hua et al. [5] & M & 52 & Asian & $\begin{array}{l}\text { Localized } \\
\text { distal CBD }\end{array}$ & $\begin{array}{l}\text { Surgical } \\
\text { specimen }\end{array}$ & 6 months & $\begin{array}{l}\text { Laparotomy } \\
+ \text { mass } \\
\text { resection. }\end{array}$ & $\begin{array}{l}\text { Jaundice, } \\
\text { pruritus }\end{array}$ \\
\hline 11 & $\begin{array}{l}\text { Welsh et al. } \\
\qquad[13\end{array}$ & $\mathrm{F}$ & 55 & Caucasian & $\begin{array}{l}\text { Localized } \\
\text { distal CBD }\end{array}$ & EUS & 4 months & PPPD & $\begin{array}{l}\text { Jaundice, } \\
\text { Abdominal } \\
\text { pain. }\end{array}$ \\
\hline 12 & $\begin{array}{l}\text { Present case } \\
\text { (2016) }\end{array}$ & M & 69 & Caucasian & diffuse & EUS & 3 weeks & Chemotherapy & $\begin{array}{c}\text { Abdominal } \\
\text { pain, Jaundice }\end{array}$ \\
\hline
\end{tabular}

PPPD = Pylorus Preserving Pancreatoduodectomy, PD= Pancreatoduodectomy, N/A= Not Available

Table 2: Median survival in different tumor pathology.

\begin{tabular}{|c|c|c|}
\hline Tumor pathology & $\begin{array}{c}\text { Median survival } \\
\text { (months) }\end{array}$ & Reference \\
\hline Non-SRC gastric carcinoma & 44 & 2 \\
\hline SRC gastric carcinoma & 21 & 21 \\
\hline $\begin{array}{c}\text { Non-SRC cholangiocarcinoma } \\
\text { unresectable }\end{array}$ & $5-15$ & 22 \\
\hline $\begin{array}{c}\text { Non-SRC Cholangiocarcinoma } \\
\text { after Ro resection }\end{array}$ & $18-33$ & $3-13$ \\
\hline SRC cholangiocarcinoma
\end{tabular}

This case is unique for several reasons. First, all cases of SRC cholangiocarcinoma reported so far described a tumor mass: In 7 cases the mass was localized to the CBD, in 3 other cases the mass was in the bifurcation of the hepatic ducts and one unknown origin. In contrast, SRC in other organs - stomach, increasing incidence and/or increasing awareness can be seen: from 0.14 cases per year between 1999-2006, to one case a year between 2007-2014, to two cases per year in 2015-2016. The main demographic and clinical data are summarized in table 1. Asian ethnicity is predominant with an equal distribution of males and females. All patients initially presented with jaundice. 
method (66-90\% sensitivity, $90-100 \%$ specificity vs $50 \%$ sensitivity, 53\% specificity respectively) [19]. EUS is particularly useful in patients without a definite mass lesion seen on cross sectional imaging [20] (Figure 2-4).

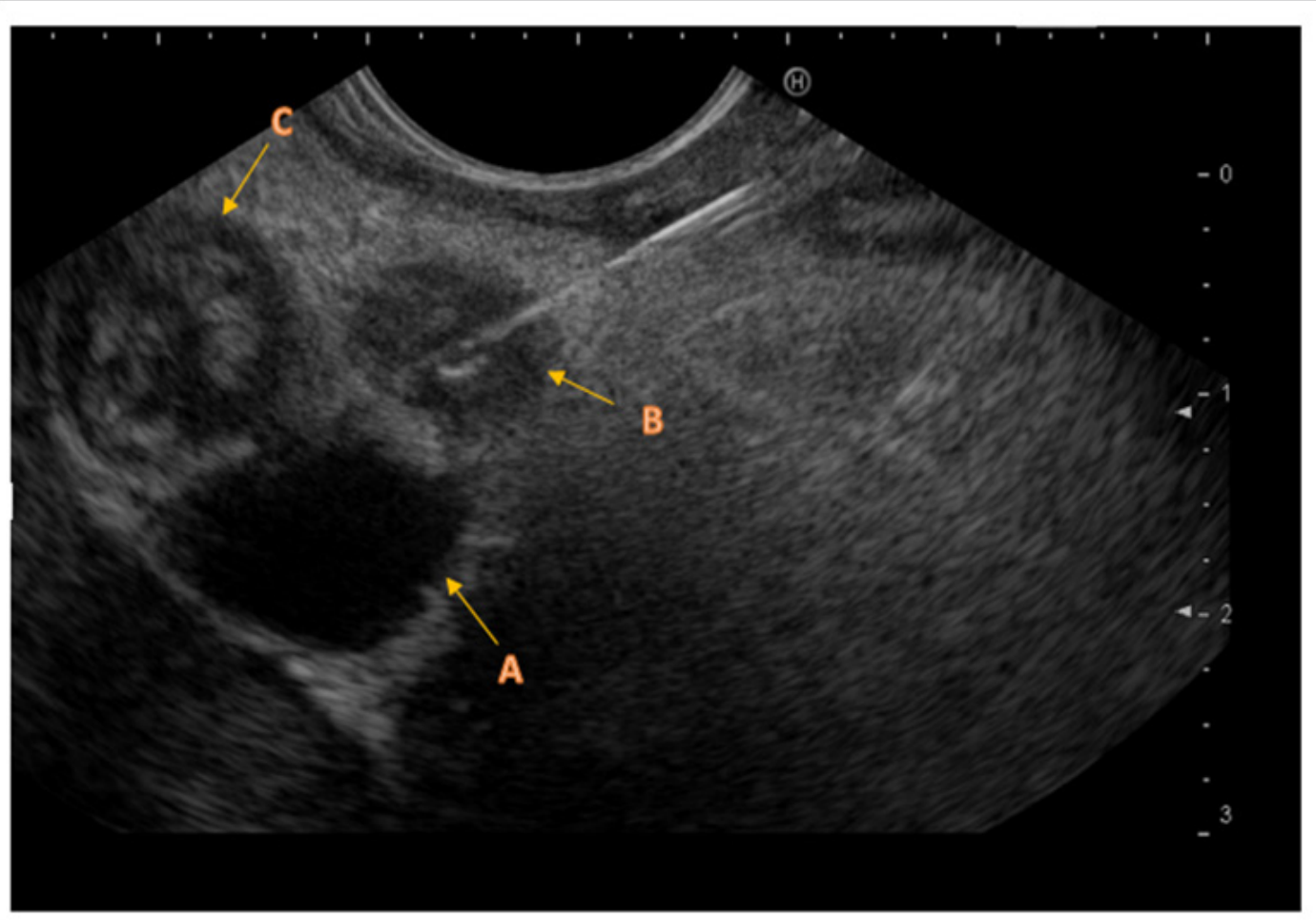

Figure 2: Endoscopic US. A- Portal vein. B- Needle biopsies taken from common bile duct. C- Enlarged lymph node.

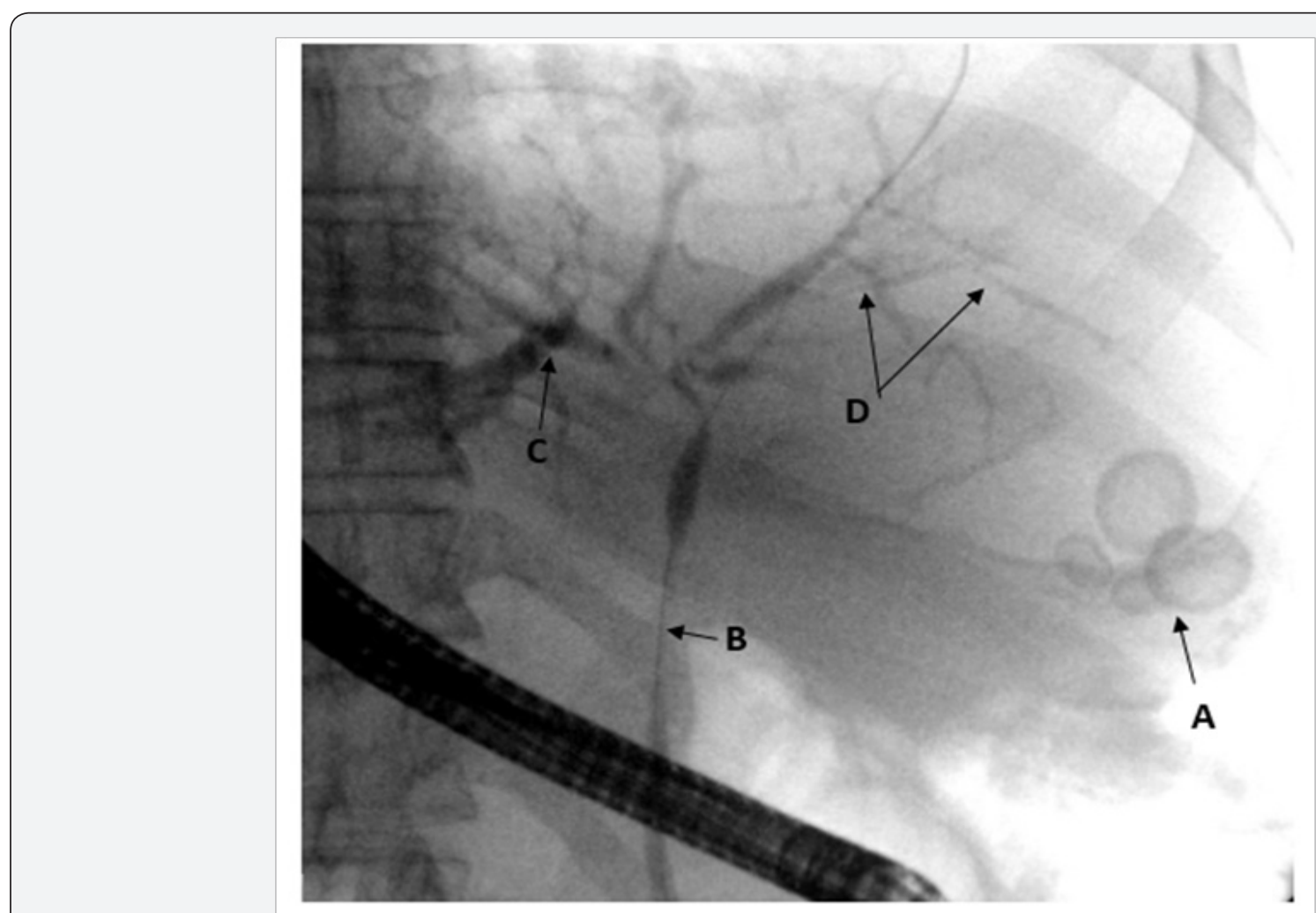

Figure 3: Endoscopic Retrograde Cholangioscopy. A- Gall stones in the gallbladder, B- Stricture of the common biliary duct, C- Segmental intra hepatic dilatation, D- Poorly filling intra hepatic ducts. 


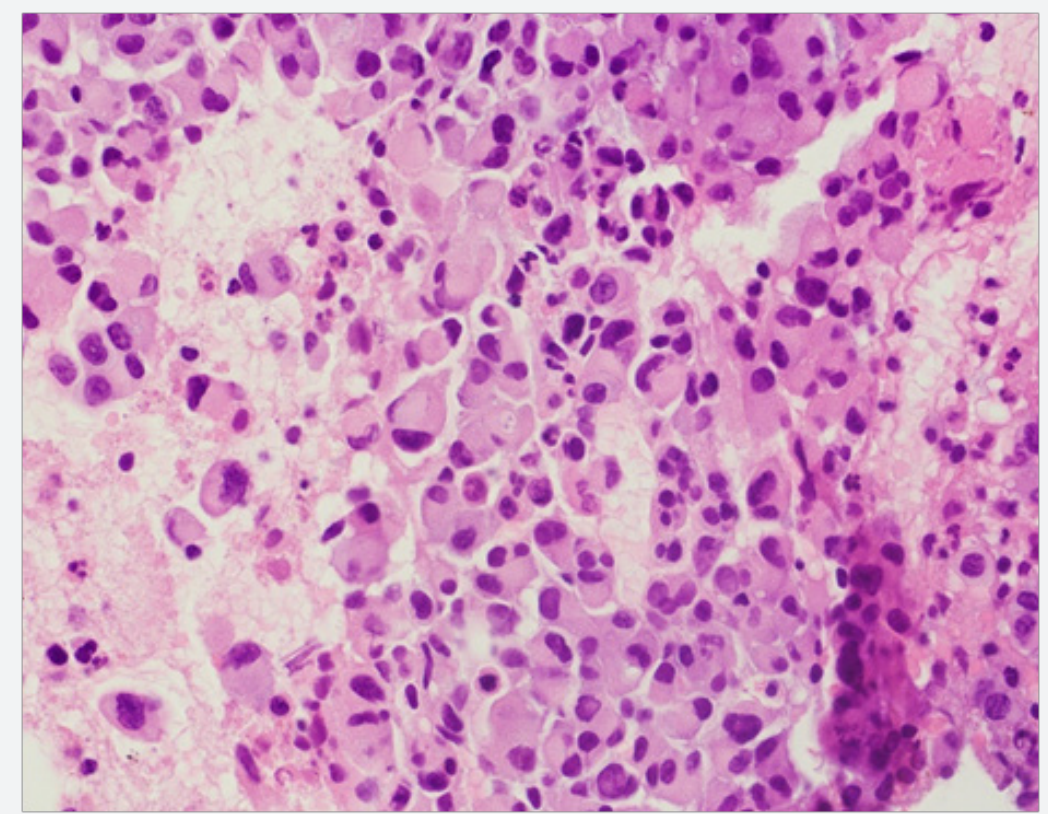

Figure 4: Core needle biopsy from the CBD, H\&E stainingX400. Arrows show signet ring cells.

This appears to be the first description of diffuse-type SRC cholangiocarcinoma. While limited in scope, it appears to suggest an extremely aggressive pathological sub-type of cholangiocarcinoma, leading to poor clinical outcomes and a short survival time. As the incidence of SRC's in general as well as the incidence of SRC cholangiocarcinoma seem to be on the rise, more cases will be encountered. If our observation is confirmed, then perhaps palliative care only should be undertaken in patient with biopsy confirmed diffuse-type SRC cholangiocarcinoma..

\section{References}

1. Longo (2014)Harrison's principles of internal medicine (18 $\left.{ }^{\text {th }}\right)$, NY: McGraw-Hill, New York, USA, p. 1854

2. Mosconi (2009) Cholangiocarcinoma. Critical Review in OncologyHematology 69(3): 259-270.

3. Chedid MF, Lucas ET, Cerski CT, Lopes MF, Amaral OB, et al. (2015) Signet-ring cell hilar cholangiocarcinoma: case report. ABCD. Arquivos Brasileiros de Cirurgia Digestiva (São Paulo) 28(2): 148-149.

4. Hiraki M, Yakushiji H, Hashiguchil K, Harada S, Okada K, et al. (2007) Signet ring cell carcinoma of the lower bile duct with rapid growth: report of a case. Hepatogastroenterology 54(79): 1922-1924.

5. Hua R, Zhang JF, Liu W, Huo YM, Sun YW (2015) Signet-ring cell carcinoma coexisting with adenocarcinoma arising in a choledochal cyst: report of a case. Surgery today 45(8): 1049-1052.

6. Kita (2014) Signet ring cell carcinoma of the extra hepatic bile duct diagnosed by preoperative biopsy: a case report. Case reports in gastroenterology 8(3) 353-357.

7. Kwon HJ, Yoon GS, Kwon YC, Kim SG, Jeong JY (2014) Signet-Ring Cell Carcinoma of the Distal Common Bile Duct: Report of a Case. Korean journal of pathology 48(4): 315-318.

8. Lee EY, Kim C, Kim MJ, Park JY, Park SW, et al. (2010) Signet ring cell carcinoma of the extrahepatic bile duct. Gut Liver 4(3): 402-406.

9. Matsumoto T, Inoue $\mathrm{S}$, Masuo $\mathrm{K}$, Okamoto $\mathrm{Y}$, Fukushima M, et al. (2011) Signet ring cell carcinoma of the bile duct: a case report. Nihon Shokakibyo Gakkai Zasshi 108: 2042-2049.
10. Mizukami Y, Ohta H, Arisato S, Nakano Y, Murakami M, et al. (1999) CASE REPORT: Mucinous cholangiocarcinoma featuring a multicystic appearance and periportal collar in imaging. Journal of gastroenterology and hepatology 14(12): 12 1223-1226.

11. Ogata S, Kimura A, Hatsuse K, Yamamoto J, Shimazaki H, et al. (2010) Poorly differentiated adenocarcinoma with signet-ring cell carcinoma of the extrahepatic bile duct in a 42-year-old Japanese female: a case report. Acta Med Okayama 64(1): 63-65.

12. Somer LJ, Andrejić BO, Milošević PA (2012) Origin and pathological characteristics of Klatskin tumor: a case report and literature review. Pol J Pathol 63(1): 65-70.

13. Welsh JL, Jaber O, Ivanovic M, Johlin FC, El Abiad RG, et al. (2016) Rapidly Progressing Primary Extrahepatic Bile Duct Signet-Ring Cell Carcinoma in a Caucasian Woman. Journal of gastrointestinal cancer.

14. Bartella, Isabel, Jean D (2015) Clinical Diagnosis and Staging of Intrahepatic Cholangiocarcinoma. Journal of gastrointestinal and liver diseases: JGLD 24(4): 481-489.

15. Aster JC, Abbas AK, Robbins L, Kumar V (2013) Robbins basic pathology, $\left(9^{\text {th }}\right)$, PA: Elsevier Saunders, Philadelphia, USA, pp. 773-777

16. Chul K, Susanna U, Julius S, Jaydira, Austin D, et al. (2016) Epidemiology and survival in patients with extragastric signet ring carcinoma. Cancer Research 76(14): 3421-3421.

17. Piessen G, Messager M, Leteurtre E, Jean-Pierre T, Mariette C (2009) Signet ring cell histology is an independent predictor of poor prognosis in gastric adenocarcinoma regardless of tumoral clinical presentation. Annals of surgery 250(6): 878-887.

18. Kang H, O'Connell JB, Maggard MA, Sack J, Ko CY (2005) A 10-year outcomes evaluation of mucinous and signet-ring cell carcinoma of the colon and rectum. Diseases of the colon \& rectum 48(6): 1161-116.

19. Weilert F, Bhat YM, Binmoeller KF, Kane S, Jaffee IM, et al. (2014) EUSFNA is superior to ERCP-based tissue sampling in suspected malignant biliary obstruction: results of a prospective, single-blind, comparative study. Gastrointestinal endoscopy 80(1): 97-104.

20. Navaneethan U, Njei B, Venkatesh PG, Lourdusamy V, Sanaka MR (2015) Endoscopic ultrasound in the diagnosis of cholangiocarcinoma as the etiology of biliary strictures: a systematic review and meta-analysis. Gastroenterology Report 3(3): 209-215. 
21. Endo I, Gonen M, Yopp AC, Dalal KM, Zhou Q, et al. (2015) Intrahepatic cholangiocarcinoma: rising frequency, improved survival, and determinants of outcome after resection. Annals of surgery 248(1): 84-96.
22. Mavros MN, Economopoulos KP, Alexiou VG, Pawlik TM (2014) Treatment and prognosis for patients with intrahepatic cholangiocarcinoma: systematic review and meta-analysis. JAMA surgery 149(6): 565-574 